\title{
Short communication: Limitations of glucose tolerance tests in the assessment of peripheral tissue insulin sensitivity during pregnancy and lactation in dairy heifers
}

\author{
J. De Koster, ${ }^{* 1}$ M. Van Eetvelde, ${ }^{*}$ K. Hermans, ${ }^{*}$ W. Van den Broeck, $†$ M. Hostens, ${ }^{*}$ and G. Opsomer* \\ *Department of Reproduction, Obstetrics and Herd Health, and \\ †Department of Morphology, Faculty of Veterinary Medicine, Ghent University, Salisburylaan 133, 9820 Merelbeke, Belgium
}

\begin{abstract}
The aim of the present study was to point at the limitations of glucose tolerance tests (GTT) to assess peripheral tissue insulin sensitivity in dairy heifers in different physiological states (pregnancy and lactation). Intravenous GTT were performed in 5 nonpregnant, nonlactating heifers, 5 heifers at the end of pregnancy (12-7 d before calving), and 5 lactating primiparous cows (11-14 d after calving). Glucose and insulin concentrations were determined and area under the curve (AUC) and clearance rate of glucose and insulin were calculated. Additionally, data were analyzed using the minimal model to derive the insulin sensitivity parameter $(\mathrm{Si})$. Basal glucose and insulin concentrations were greater in the nonpregnant, nonlactating heifers. Clearance rate of glucose and $\mathrm{Si}$ were lowest, whereas the AUC for glucose was greatest in the nonpregnant, nonlactating heifers. Insulin concentrations during the GTT were greater for the nonpregnant, nonlactating heifers. Results from the GTT in pregnant heifers and lactating primiparous cows are biased by the fact that a large part of the glucose disappearance during an intravenous GTT occurs independently of insulin by the pregnant uterus or the lactating mammary gland. As such, greater AUC of glucose, lower clearance rate of glucose, or lower $\mathrm{Si}$ derived from GTT performed in nonpregnant, nonlactating dairy heifers in the present study might indicate decreased peripheral tissue insulin sensitivity of the glucose metabolism or decreased insulin-independent glucose disappearance. Based on the results from a GTT, it is impossible to discriminate between both metabolic pathways. It can be concluded that parameters derived from GTT are not suited to compare peripheral tissue insulin sensitivity of the glucose metabolism between dairy heifers in different physiological states due to the large variation
\end{abstract}

Received July 28, 2016.

Accepted November 29, 2016.

${ }^{1}$ Corresponding author: jenne.dekoster@ugent.be in insulin secretion and the substantial difference in insulin-independent glucose disposal associated with these physiological states.

Key words: glucose tolerance test, pregnancy, lactation, insulin resistance

\section{Short Communication}

Glucose tolerance tests (GTT) are frequently used to assess insulin sensitivity in dairy cows (Holtenius et al., 2003; Chagas et al., 2009). The plasma glucose profile during a GTT is the reflection of total body glucose metabolism after an intravenous glucose bolus (Ferrannini and Mari, 1998; De Koster and Opsomer, 2013). The total body glucose metabolism can be subdivided into insulin-independent and insulin-dependent glucose metabolism. The insulin-dependent glucose metabolism is influenced by the increase in insulin concentration after an intravenous glucose bolus and stimulates insulin-sensitive tissues (mainly skeletal muscle and, to a lesser extent, adipose tissue) to increase SLC2A4 (solute carrier family 2, facilitated glucose transporter member 4; formerly known as GLUT4) translocation to the plasma membrane followed by a subsequent increase in glucose uptake. The response of insulin-sensitive tissues to insulin determines the insulin resistance of the animal (Kahn, 1978; De Koster and Opsomer, 2013).

The insulin-independent glucose metabolism is not influenced by the increased insulin concentration during the GTT, but is mainly determined by the capacity of an increased glucose concentration to enhance its own disappearance and to inhibit hepatic glucose output (Bergman, 2007; Muniyappa et al., 2008). In nonpregnant, nonlactating animals, the insulinindependent glucose disappearance occurs mainly via glucose transporter 1 (GLUT1) in different tissues and by excretion via the kidney (only small amounts, 2 to $4 \%$ of the glucose bolus; Grünberg et al., 2011). In pregnant animals, a large part of the circulating glucose (60 to $70 \%$ ) is taken up independently of insulin by the pregnant uterus via GLUT1 and GLUT3 (Bell et al., 
2000; Grünberg et al., 2011). This uptake is even more pronounced in lactating animals, in which the insulinindependent glucose uptake by the udder via GLUT1 increases glucose requirements substantially (De Koster and Opsomer, 2013). In lactating cows, insulin-independent glucose uptake by the udder was estimated to be responsible for 80 to $82 \%$ of whole body glucose turnover (Bickerstaffe et al., 1974; Bell and Bauman, 1997; Rose et al., 1997).

The ability of a test to assess the insulin sensitivity of the glucose metabolism is dependent on its ability to differentiate between the effect of insulin to enhance glucose disappearance and all other factors influencing glucose disappearance (De Koster et al., 2016). Several different tests have been used to assess insulin resistance in dairy cows. Surrogate indices for insulin sensitivity (calculated from glucose, insulin, fatty acids, and BHB concentrations in blood) were unreliable to assess insulin resistance in dairy cows at the end of the dry period due to inherent differences in metabolism between humans and ruminants. In humans, insulin resistance is characterized by high insulin or high glucose concentrations, whereas the metabolism of dry and lactating cows is characterized by low glucose and low insulin concentrations (Bloomgarden, 2006; De Koster and Opsomer, 2013; De Koster et al., 2016). In humans, elevated concentrations of triglycerides have been associated with insulin resistance (Bloomgarden, 2006), whereas fatty acids and BHB in dairy cows are reflections of negative energy balance rather than a state of insulin resistance (Ospina et al., 2013; De Koster et al., 2016). Parameters derived from GTT (area under the curve for glucose, insulin sensitivity index derived from the minimal model) were proven to be reliable estimates of insulin resistance in dairy cows at the end of the dry period (De Koster et al., 2016). Dairy cows generally are in a lactating or pregnant state, leading, in large part, to glucose disappearance being insulinindependent (60 to 82\%; Rose et al., 1997; De Koster and Opsomer, 2013) and making it difficult to interpret and compare parameters derived from GTT performed in cows in different physiological states (Marett et al., 2015). In the literature, however, multiple examples can be found in which GTT has been used to measure and compare insulin resistance in cows in different physiological states without taking into account the potential difference in insulin-independent glucose disappearance or differences in glucose-induced insulin secretion (Chalmeh et al., 2015; Oliveira et al., 2016). The aim of the present study was to point at the limitations of GTT to assess peripheral tissue insulin sensitivity in dairy heifers in different physiological states (pregnancy and lactation). We hypothesized that the results from GTT would differ depending on the physiological state of the animals, but interpretation of the parameters derived from GTT would be indefinite in terms of insulin resistance.

All experimental procedures were approved by the ethical committee of the Faculty of Veterinary Medicine (EC2015/142 - Ghent University, Belgium). Intravenous GTT were performed in nonpregnant, nonlactating heifers (NON, $\mathrm{n}=5$ ), pregnant, nonlactating heifers 12 to $7 \mathrm{~d}$ before calving (PREG, $\mathrm{n}=5$ ), and nonpregnant, lactating primiparous cows 11 to $14 \mathrm{~d}$ after calving ( $\mathbf{L A C T}, \mathrm{n}=5$ ). On the day of the GTT, heifers were weighed, BCS was assessed according to the scale of Edmonson et al. (1989), and back fat thickness (BFT) was determined as described by Schröder and Staufenbiel (2006). A catheter (Cavafix Certo 338-14G, B. Braun, Instrulife, Oostkamp, Belgium) was placed in the left jugular vein and heifers were allowed to rest for a period of $2 \mathrm{~h}$. Glucose was infused at a dose of $150 \mathrm{mg} / \mathrm{kg}$ of BW (Glucose 30\%, Eurovet, Verdifarm, Beringen-Paal, Belgium) over a period of 2 to $4 \mathrm{~min}$, after which the catheter was flushed 2 times with 20 $\mathrm{mL}$ of saline. Time point 0 was the moment when all the glucose was infused. Blood samples for determination of glucose and insulin were taken at following time points: $-15,-5,0,2,4,6,8,10,12,15,18,20,23,26$, $30,35,40,45,50,60,90,120,150$, and $180 \mathrm{~min}$. From $2 \mathrm{~h}$ before until the end of the GTT, heifers had access to fresh drinking water but not feed.

Samples for plasma glucose determination were taken in fluoride blood tubes (Vacutest, Novolab, Geraardsbergen, Belgium). Samples for serum insulin determination were taken in gel-coated blood tubes (Vacutest, Novolab). Within $2 \mathrm{~h}$ after collection, all blood samples were centrifuged for $20 \mathrm{~min}\left(2,460 \times g, 7^{\circ} \mathrm{C}\right)$ and serum and plasma were stored at $-20^{\circ} \mathrm{C}$ until analysis. Plasma glucose concentrations were determined using a colorimetric hexokinase method on a Cobas 6000 analyzer (Roche Diagnostics, Mannheim, Germany), and intraand interassay coefficient of variation were 0.82 and $1.1 \%$, respectively. Serum insulin concentrations were determined using a bovine-specific commercial ELISA kit (Bovine Insulin ELISA, catalog no. 10-1201-01, Mercodia, Uppsala, Sweden), and intra- and interassay CV were 2.9 and $10.8 \%$, respectively. Conversion of insulin concentrations from gravimetric units to international units was done as described by Abuelo et al. (2012).

Based on the measured glucose and insulin concentrations during the GTT, different measures of insulin sensitivity were calculated. The clearance rate $(\mathbf{C R})$ of glucose between 0 and $30 \mathrm{~min}$ and 0 and $60 \mathrm{~min}$ and the clearance rate of insulin between 15 and 30 min were 
Table 1. Age, weight, BCS, back fat thickness (BFT), and realized 305-d milk production of the nonpregnant, nonlactating heifers (NON), pregnant heifers (PREG), and lactating primiparous cows (LACT) (means \pm SEM)

\begin{tabular}{lcrrr}
\hline Item & NON & PREG & LACT & $P$-value \\
\hline Age $^{2}(\mathrm{mo})$ & $27.8 \pm 3.2$ & $23.5 \pm 0.6$ & $24.2 \pm 0.7$ & 0.283 \\
Weight $(\mathrm{kg})_{\text {BCS }^{3}}$ & $484.2 \pm 20.0^{\mathrm{a}}$ & $579.6 \pm 8.9^{\mathrm{b}}$ & $523.8 \pm 8.9^{\mathrm{a}}$ & 0.001 \\
BFT $^{4}(\mathrm{~cm})$ & $2.70 \pm 0.15$ & $3.10 \pm 0.17$ & $3.00 \pm 0.16$ & 0.218 \\
305-d milk production $^{5}(\mathrm{~kg})$ & $0.87 \pm 0.09$ & $0.96 \pm 0.19$ & $1.10 \pm 0.17$ & 0.591 \\
\hline
\end{tabular}

${ }^{\mathrm{a}, \mathrm{b}}$ Means within a row with different superscripts differ (Tukey post hoc test, $P<0.05$ ).

${ }^{1} P$-values of the ANOVA for group differences.

${ }^{2}$ Age at the moment of the glucose tolerance test.

${ }^{3}$ Body condition score according to the scale of Edmonson et al. (1989).

${ }^{4}$ Backfat thickness as described by Schröder and Staufenbiel (2006).

${ }^{5}$ Realized 305-d milk production.

calculated as described by Pires et al. (2007). The area under the curve (AUC) of glucose and insulin were calculated between 0 and $60 \mathrm{~min}$, between 0 and $120 \mathrm{~min}$, and between 0 and $180 \mathrm{~min}$ as the incremental AUC using the trapezoidal rule as described by Cardoso et al. (2011). Glucose and insulin data derived from the GTT were fitted using MINMOD Millenium software (MINMOD Inc., Pasadena, CA; Boston et al., 2003) based on the minimal model as described by Bergman et al. (1979). The derived variables of interest were the insulin sensitivity index $(\mathbf{S i})$ and the glucose effectiveness $(\mathbf{S g})$. The Si is a measure describing the ability of insulin to increase glucose disappearance. The $\mathrm{Sg}$ is a measure describing the ability of glucose to enhance its own disappearance, independent of insulin (Bergman et al., 1979). For model fitting purposes in the MINMOD program, the results of the GTT were adapted as follows: basal glucose and insulin concentrations measured at time -15 and -5 min were averaged and assigned to time point $0 \mathrm{~min}$ in the MINMOD program; insulin and glucose concentrations measured at time point 0 min were assigned to time point $2 \mathrm{~min}$ in the MINMOD program; results from the first $8 \mathrm{~min}$ during the GTT were zero-weighted to allow for glucose mixing; and basal values for glucose and insulin were added at time points 240 and 300 min (Bergman et al., 1979; Pacini and Bergman, 1986; Boston et al., 2003). The curves generated by the MINMOD program were evaluated by visual assessment of the fit of the curves with the original data, the fractional standard deviation $(<15 \%)$ and the coefficient of determination $\left(\mathrm{R}^{2}>95 \%\right.$; Pacini and Bergman, 1986).

Statistical analyses were performed using SAS version 9.4 (SAS Institute Inc., Cary, NC). Descriptive statistics (PROC MEANS) are expressed as means \pm standard error of the means unless otherwise indicated. Normality of the variables (PROC UNIVARIATE) was checked using the Kolmogorov-Smirnov test. All variables were compared in an ANOVA model with group as independent variable ( 3 categories: NON, PREG, and LACT). Homoscedasticity was checked using the Levene's test. When variances within groups differed significantly, variables were $\log _{10}$-transformed. Conclusions made after log-transformation of the data were similar compared with the nontransformed data. Pairwise comparisons were made between groups using the Tukey honestly significant difference test. Differences between groups were declared significant at $P<0.05$.

The age, BCS, BFT, weight, and realized 305-d milk production of the heifers are given in Table 1. Pregnant heifers were heavier compared with the 2 other groups most probably due to the weight of the fetus, uterus, and amniotic and allantoic fluids. Fatter cows and heifers have lower insulin sensitivity (McCann and Reimers, 1985; De Koster et al., 2015). In the present study, the degree of fatness as measured by the BCS and BFT did not differ between the groups. The NON heifers, although over 27 mo of age, on average, had not been bred due to the fact that they had been used for ovum pickup.

Basal glucose and insulin concentration were greater in the NON group compared with the PREG and LACT group (Table 2). Following the glucose infusion, peak glucose concentration was greater in the NON group, most likely due to the greater basal glucose concentration and the lower glucose requirements (Figure 1, Table 2). Whereas the glucose AUC was larger for every calculated interval in the NON group, the glucose CR was lower only for the interval between 0 and $30 \mathrm{~min}$. Insulin secretion, as measured by peak insulin concentration and AUC, was greater in the NON group, followed by the PREG group, with the lowest insulin secretion in the LACT group (Figure 1, Table 2). Whole-body response to a glucose load in dairy 
heifers can be partitioned into insulin secretion by the pancreas and insulin-dependent and -independent glucose disappearance.

For the interpretation of parameters derived from GTT, one needs first to consider the difference in glucose induced insulin secretion by the pancreas between the groups (Ferrannini and Mari, 1998). Following the glucose bolus, insulin concentration increased more in NON heifers. In every group large variation in insulin secretion occurred between the animals, especially in the NON and the PREG group. The large variability of the serum insulin concentration between animals during a GTT has been observed previously by others (Marett et al., 2015). Serum insulin concentrations are influenced by the insulin sensitivity and the physiological state of the animal. From human medicine, it is known that, as a compensation mechanism to guarantee glucose homeostasis, insulin secretion is greater in insulin-resistant individuals and pregnant women (Kahn, 2003; Buchanan et al., 2012). In case the pancreas is unable to increase its insulin secretion, type-2 diabetes mellitus or gestational diabetes mellitus will develop (Kahn, 2003; DeFronzo, 2004; Buchanan et al., 2012). Due to the large difference in glucose metabolism between ruminants and monogastrics (De Koster and Opsomer, 2013), it is currently unknown whether the same hyperbolic relationship between peripheral tissue insulin resistance and insulin secretion is evident in dairy cows as well.

In dairy cows, it is known that insulin secretion is decreased at the end of pregnancy and the initiation of lactation. This is a normal phenomenon supporting the metabolic need to redirect glucose from peripheral tissues toward the uterus and mammary gland to support the growing fetus or nursing neonate (Ingvartsen and Andersen, 2000; Bossaert et al., 2008). Additionally, liver blood flow and metabolic activity increase tremendously in cows at the beginning of lactation, which might contribute to lower insulin levels due to its greater metabolic clearance by the liver (Mann et al., 2016), as demonstrated by the greater insulin CR in the LACT group (Table 2). Another possible interpretation of our results could be that the glucose-induced insulin secretion was lower in the LACT and PREG group due to the lower peak glucose, which might have been due to the flux of glucose toward the mammary gland and the uterus. In the present study, no significant differences in insulin AUC were observed between the PREG and LACT group, although the LACT group had numerically lower insulin AUC (Table 2). In other studies using multiparous cows, greater glucose-induced insulin secretion by the pancreas was measured in the

Table 2. Results of the ANOVA for group differences for the parameters derived from the glucose tolerance tests (GTT) performed in nonpregnant, nonlactating heifers (NON), pregnant heifers (PREG), and lactating primiparous cows (LACT) (means \pm SEM)

\begin{tabular}{|c|c|c|c|c|}
\hline Item & $\mathrm{NON}$ & PREG & LACT & $P$-value ${ }^{1}$ \\
\hline Basal glucose ${ }^{2}(\mathrm{mg} / \mathrm{dL})$ & $74.3 \pm 1.9^{\mathrm{a}}$ & $64.5 \pm 3.4^{\mathrm{b}}$ & $59.5 \pm 2.92^{\mathrm{b}}$ & 0.009 \\
\hline Basal insulin ${ }^{3}(\mu \mathrm{IU} / \mathrm{mL})$ & $14.11 \pm 1.49^{\mathrm{a}}$ & $5.91 \pm 1.98^{\mathrm{b}}$ & $3.39 \pm 0.65^{\mathrm{b}}$ & 0.001 \\
\hline Peak glucose ${ }^{4}(\mathrm{mg} / \mathrm{dL})$ & $203 \pm 6.0^{\mathrm{a}}$ & $163 \pm 9.0^{\mathrm{b}}$ & $153 \pm 11.0^{\mathrm{b}}$ & 0.005 \\
\hline Peak insulin ${ }^{5}(\mu \mathrm{IU} / \mathrm{mL})$ & $186.6 \pm 44.9^{\mathrm{a}}$ & $70.7 \pm 26.7^{\mathrm{b}}$ & $76.5 \pm 7.1^{\mathrm{ab}}$ & 0.026 \\
\hline $\mathrm{CR}_{0-30, \text { glucose }}{ }^{6}(\% / \mathrm{min})$ & $1.73 \pm 0.25^{\mathrm{a}}$ & $2.26 \pm 0.08^{\mathrm{ab}}$ & $2.75 \pm 0.20^{\mathrm{b}}$ & 0.010 \\
\hline $\mathrm{CR}_{0-60, \text { glucose }}(\% / \mathrm{min})$ & $1.40 \pm 0.18$ & $1.59 \pm 0.09$ & $1.66 \pm 0.08$ & 0.353 \\
\hline $\mathrm{CR}_{15-30 \text {,insulin }}{ }^{7}(\% / \mathrm{min})$ & $2.42 \pm 0.35^{\mathrm{a}}$ & $3.61 \pm 1.15^{\mathrm{a}}$ & $6.83 \pm 0.40^{\mathrm{b}}$ & 0.003 \\
\hline $\operatorname{AUC} 0_{\text {glucose }}(\mathrm{mg} / \mathrm{dL} \times 60 \mathrm{~min})$ & $3,875 \pm 184^{\mathrm{a}}$ & $2,802 \pm 172^{\mathrm{b}}$ & $1,860 \pm 158^{\mathrm{c}}$ & $<0.001$ \\
\hline AUC 120 glucose $^{8}(\mathrm{mg} / \mathrm{dL} \times 120 \mathrm{~min})$ & $4,508 \pm 367^{\mathrm{a}}$ & $3,147 \pm 397^{\mathrm{b}}$ & $2,082 \pm 202^{\mathrm{b}}$ & 0.001 \\
\hline AUC180 8 glucose $(\mathrm{mg} / \mathrm{dL} \times 180 \mathrm{~min})$ & $4,751 \pm 357^{\mathrm{a}}$ & $3,117 \pm 489^{\mathrm{b}}$ & $2,238 \pm 235^{\mathrm{b}}$ & 0.002 \\
\hline $\operatorname{AUC60}_{\text {insulin }}^{9}(\mu \mathrm{IU} / \mathrm{mL} \times 60 \mathrm{~min})$ & $6,120 \pm 1,528^{\mathrm{a}}$ & $1,759 \pm 567^{\mathrm{b}}$ & $1,505 \pm 162^{\mathrm{b}}$ & 0.004 \\
\hline AUC120 ${ }_{\text {insulin }}{ }^{9}(\mu \mathrm{IU} / \mathrm{mL} \times 120 \mathrm{~min})$ & $6,636 \pm 1,669^{\mathrm{a}}$ & $1,793 \pm 556^{\mathrm{b}}$ & $1,495 \pm 163^{\mathrm{b}}$ & 0.003 \\
\hline $\mathrm{AUC} 180_{\text {insulin }}{ }^{9}(\mu \mathrm{IU} / \mathrm{mL} \times 180 \mathrm{~min})$ & $6,471 \pm 1,664^{\mathrm{a}}$ & $1,745 \pm 536^{\mathrm{b}}$ & $1,496 \pm 177^{\mathrm{b}}$ & 0.004 \\
\hline $\mathrm{Si}^{10}\left[\times 10^{-4}(\mu \mathrm{IU} / \mathrm{mL})^{-1}\right.$ per min $]$ & $0.95 \pm 0.29^{\mathrm{a}}$ & $3.99 \pm 1.37^{\mathrm{b}}$ & $3.83 \pm 0.43^{\mathrm{b}}$ & 0.005 \\
\hline $\mathrm{Sg}^{11^{2}}($ per min $)$ & $0.017 \pm 0.003$ & $0.021 \pm 0.004$ & $0.027 \pm 0.008$ & 0.424 \\
\hline
\end{tabular}

\footnotetext{
${ }^{\mathrm{a}-\mathrm{c}}$ Means within a row with different superscripts differ (Tukey post hoc test, $P<0.05$ ).

${ }^{1} P$-values of the ANOVA for group difference.

${ }^{2}$ Average glucose concentration in blood samples taken before the start of the GTT.

${ }^{3}$ Average insulin concentration in blood samples taken before the start of the GTT.

${ }^{4}$ Glucose concentration at time 0 as derived from MINMOD (MINMOD Inc., Pasadena, CA).

${ }^{5}$ The maximum insulin concentration measured during the GTT.

${ }^{6}$ Clearance rate of glucose during the first 30 and $60 \mathrm{~min}$ of the GTT.

${ }^{7}$ Clearance rate of insulin between 15 and 30 min of the GTT.

${ }^{8}$ Area under the curve of glucose during the first $60 \mathrm{~min}$, the first $120 \mathrm{~min}$ and $180 \mathrm{~min}$ of the GTT.

${ }^{9}$ Area under the curve of insulin during the first $60 \mathrm{~min}$, the first $120 \mathrm{~min}$ and $180 \mathrm{~min}$ of the GTT.

${ }^{10}$ Insulin sensitivity index derived from the minimal model.

${ }^{11}$ Glucose effectiveness derived from the minimal model.
} 
prepartum compared with the postpartum period (Holtenius et al., 2003; Kerestes et al., 2009; Mann et al., 2016; Weber et al., 2016). The difference with our study might be explained by the following factors. First of all, insulin secretion following a glucose bolus in the prepartum period decreases as calving approaches (Regnault et al., 2004; Mann et al., 2016). Therefore, the close timing to calving in the present study (12 to $7 \mathrm{~d}$ before calving and 11 to $14 \mathrm{~d}$ after calving) might limit the distinction between the pre- and postpartum insulin secretion. Second, the low number of animals in the different groups might limit the distinction between the PREG and LACT group. Finally, metabolic differences between heifers and cows may influence parameters derived from GTT, not only due to the inherently lower milk yield in heifers but also due to the requirements of metabolites for continued growth while pregnant or lactating (NRC, 2001). Adolescent animals prioritize growth before offspring (Wallace et al., 1996; Wallace et al., 1997). Further research is needed to elucidate the difference in glucose and insulin metabolism between growing heifers and cows in the periparturient period.

To interpret the results in terms of insulin resistance, it is important to collectively evaluate the glucose and insulin curves. The AUC for glucose and insulin were significantly greater in the NON group, followed
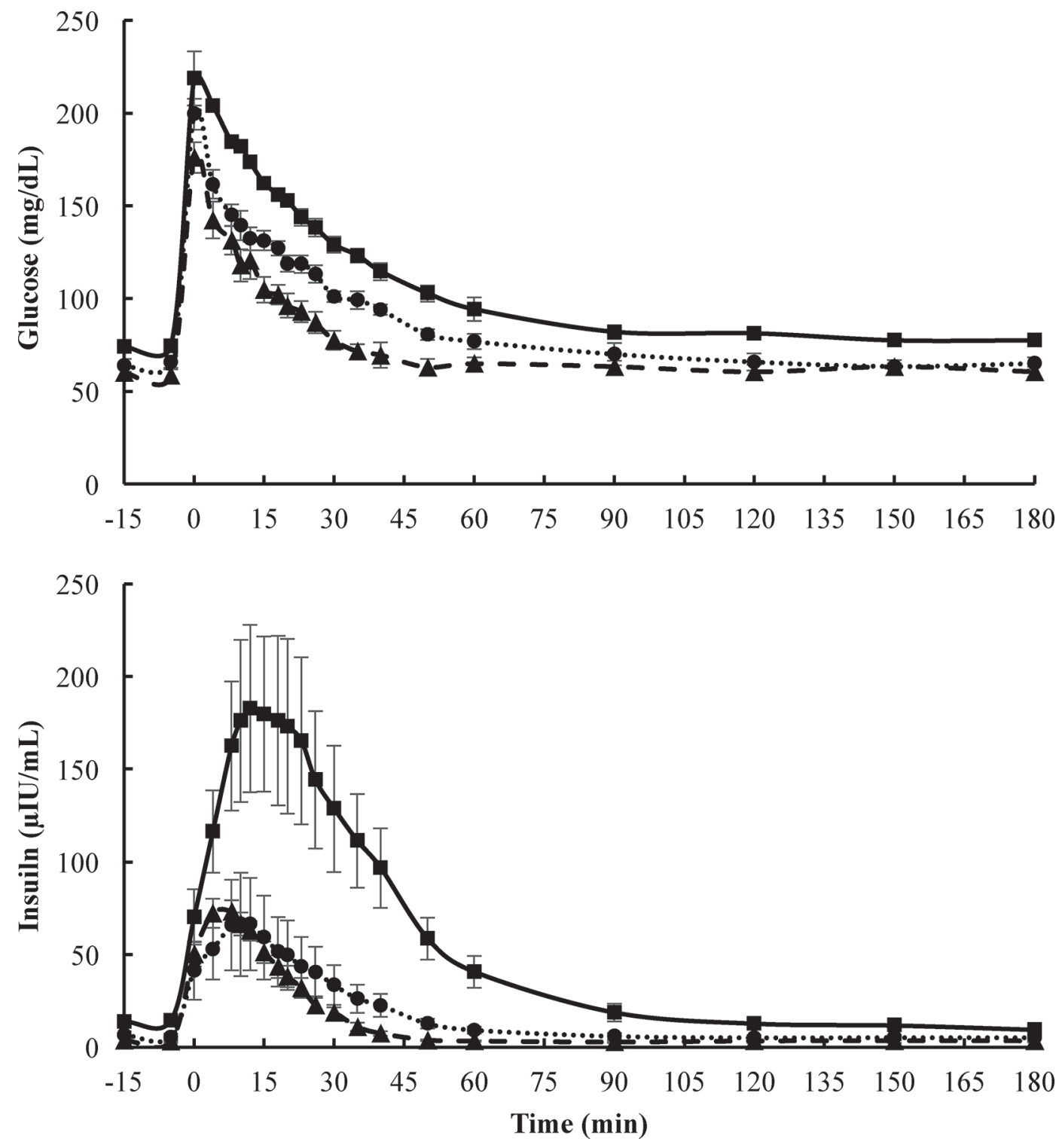

Figure 1. Glucose $(\mathrm{mg} / \mathrm{dL})$ and insulin concentration $(\mu \mathrm{IU} / \mathrm{mL})$ during the intravenous glucose tolerance test in 5 nonpregnant, nonlactating heifers $(\mathbf{\square})$, in 5 pregnant heifers $(\bullet)$, and in 5 lactating primiparous cows $(\mathbf{\Lambda})$. Symbols represent the average glucose and insulin concentration at each time point; error bars represent the SEM. 
by the PREG group and being lowest in the LACT group. These results can be interpreted as the NON group experienced the greatest peripheral tissue insulin resistance because they required more insulin (higher dose) while having a greater AUC for glucose (lower response). On the other hand, the LACT group had a lower insulin secretion (lower dose) while having a lower AUC for glucose (greater response), which could be interpreted as the lowest peripheral tissue insulin resistance. Using MINMOD, the glucose response is mathematically predicted using the insulin concentrations after the glucose bolus, thus accounting for differences in insulin secretion between animals (Ferrannini and Mari, 1998). The results of the MINMOD indicate a lower insulin sensitivity in the NON group (low $\mathrm{Si}$ ) in comparison with the LACT and PREG group (high $\mathrm{Si}$; Table 2). However, this is in contrast to what has generally been accepted in dairy cows; specifically, at the end of pregnancy and in the beginning of lactation, these animals are stated to be in a transient state of insulin resistance (Bell and Bauman, 1997). Hence, the parameters derived from the GTT in the present study seem to be biased by the fact that the insulinindependent glucose uptake is different according to the physiological state of the animals. In the LACT group, a large part of the infused glucose is redirected toward the mammary gland independent of insulin (Marett et al., 2015). This is associated with a faster decline of glucose (clearance rate of glucose between 0 and 30 min), a lower AUC of glucose, and numerically higher Sg during the GTT. In the PREG group, a large part (although smaller compared with that going to the mammary gland in the LACT group) of the infused glucose is redirected toward the pregnant uterus independent of insulin. Whereas in the NON group, most of the glucose is disposed in an insulin-dependent way. The difference in insulin-independent glucose disposal might explain a large part of the observed difference in glucose AUC, glucose CR, and Si between groups and might, therefore, influence the accurate interpretation of the parameters derived from GTT with regard to the insulin sensitivity of the individuals. Other methods, such as the hyperinsulinemic euglycemic clamp test using isotopes of glucose, are more suitable for the assessment of insulin-dependent and -independent glucose disappearance and to compare the insulin sensitivity of dairy heifers and cows in different physiological states (Rose et al., 1997; Weber et al., 2016).

In conclusion, the effect of physiological state on parameters derived from GTT in the present study indicate improved glucose tolerance in pregnant heifers and lactating primiparous cows compared with nonpregnant, nonlactating heifers. The latter observation might indicate increased peripheral tissue insulin sensitivity of the glucose metabolism or increased insulin-independent glucose disappearance in pregnant heifers and lactating primiparous cows (Marett et al., 2015). Based on the results from GTT, it is impossible to discriminate between both metabolic pathways. As insulin-independent glucose disappearance is a very important phenomenon in pregnant and lactating animals, this cannot be ignored in the interpretation of the parameters derived from GTT. As such, parameters derived from GTT are not indicated to compare peripheral tissue insulin sensitivity of the glucose metabolism between dairy heifers (and cows) in different physiological states (pregnant vs. lactating vs. nonpregnant, nonlactating). The underlying reason for this is the large variation in insulin secretion and the difference in insulin-independent glucose disposal between these physiological states.

\section{ACKNOWLEDGMENTS}

This research was funded by the Special Research Fund of Ghent University, grant number 01D28410. The authors wish to thank Lars Hulpio, Isabel Lemahieu, and Petra Van Damme (Department of Reproduction, Obstetrics and Herd Health, Faculty of Veterinary Medicine, Ghent University, Merelbeke, Belgium) for excellent technical assistance in the laboratory.

\section{REFERENCES}

Abuelo, A., J. De Koster, J. Hernandez, G. Opsomer, L. Grufman, and C. Castillo. 2012. Quantifying bovine insulin: Conversion of units. Vet. Clin. Pathol. 41:308-310.

Bell, A. W., and D. E. Bauman. 1997. Adaptations of glucose metabolism during pregnancy and lactation. J. Mammary Gland Biol. Neoplasia 2:265-278

Bell, A. W., R. A. Ehrhardt, and P. B. Cronje. 2000. Regulation of macronutrient partitioning between maternal and conceptus tissues in the pregnant ruminant. Pages 275-293 in Ruminant Physiology: Digestion, Metabolism, Growth and Reproduction.

Bergman, R. N. 2007. Orchestration of glucose homeostasis from a small acorn to the California oak. Diabetes 56:1489-1501.

Bergman, R. N., Y. Z. Ider, C. R. Bowden, and C. Cobelli. 1979. Quantitative estimation of insulin sensitivity. Am. J. Physiol. 236:E667-677.

Bickerstaffe, R., E. F. Annison, and J. L. Linzell. 1974. The metabolism of glucose, acetate, lipids and amino acids in lactating dairy cows. J. Agric. Sci. 82:71-85.

Bloomgarden, Z. T. 2006. Measures of insulin sensitivity. Clin. Lab. Med. 26:611-633.

Bossaert, P., J. L. Leroy, S. De Vliegher, and G. Opsomer. 2008. Interrelations between glucose-induced insulin response, metabolic indicators, and time of first ovulation in high-yielding dairy cows. J. Dairy Sci. 91:3363-3371.

Boston, R. C., D. Stefanovski, P. J. Moate, A. E. Sumner, R. M. Watanabe, and R. N. Bergman. 2003. Minmod millennium: A computer program to calculate glucose effectiveness and insulin sensitivity from the frequently sampled intravenous glucose tolerance test. Diabetes Technol. Ther. 5:1003-1015.

Buchanan, T. A., A. H. Xiang, and K. A. Page. 2012. Gestational diabetes mellitus: Risks and management during and after pregnancy Nat. Rev. Endocrinol. 8:639-649. 
Cardoso, F. C., W. Sears, S. J. LeBlanc, and J. K. Drackley. 2011. Technical note: Comparison of 3 methods for analyzing areas under the curve for glucose and nonesterified fatty acids concentrations following epinephrine challenge in dairy cows. J. Dairy Sci. 94:6111-6115.

Chagas, L. M., M. C. Lucy, P. J. Back, D. Blache, J. M. Lee, P. J. S. Gore, A. J. Sheahan, and J. R. Roche. 2009. Insulin resistance in divergent strains of Holstein-Friesian dairy cows offered fresh pasture and increasing amounts of concentrate in early lactation. J. Dairy Sci. 92:216-222.

Chalmeh, A., M. Pourjafar, S. Nazifi, F. Momenifar, and M. Mohamadi. 2015. Insulin resistance in different physiological states of high producing Holstein dairy cows. Acta Sci. Vet. 43:1-7.

De Koster, J., M. Hostens, K. Hermans, W. Van den Broeck, and G. Opsomer. 2016. Validation of different measures of insulin sensitivity of glucose metabolism in dairy cows using the hyperinsulinemic euglycemic clamp test as the gold standard. Domest. Anim. Endocrinol. 57:117-126.

De Koster, J., M. Hostens, M. Van Eetvelde, K. Hermans, S. Moerman, H. Bogaert, E. Depreester, W. Van den Broeck, and G. Opsomer. 2015. Insulin response of the glucose and fatty acid metabolism in dry dairy cows across a range of body condition scores. J. Dairy Sci. 98:4580-4592.

De Koster, J. D., and G. Opsomer. 2013. Insulin resistance in dairy cows. Vet. Clin. North Am. Food Anim. Pract. 29:299-322.

DeFronzo, R. A. 2004. Pathogenesis of type 2 diabetes mellitus. Med. Clin. North Am. 88:787-835. (ix.)

Edmonson, A. J., I. J. Lean, L. D. Weaver, T. Farver, and G. Webster. 1989. A body condition scoring chart for Holstein dairy cows. J. Dairy Sci. 72:68-78.

Ferrannini, E., and A. Mari. 1998. How to measure insulin sensitivity. J. Hypertens. 16:895-906.

Grünberg, W., S. S. Donkin, and P. D. Constable. 2011. Periparturient effects of feeding a low dietary cation-anion difference diet on acidbase, calcium, and phosphorus homeostasis and on intravenous glucose tolerance test in high-producing dairy cows. J. Dairy Sci. 94:727-745.

Holtenius, K., S. Agenas, C. Delavaud, and Y. Chilliard. 2003. Effects of feeding intensity during the dry period. 2. Metabolic and hormonal responses. J. Dairy Sci. 86:883-891.

Ingvartsen, K. L., and J. B. Andersen. 2000. Integration of metabolism and intake regulation: A review focusing on periparturient animals. J. Dairy Sci. 83:1573-1597.

Kahn, C. R. 1978. Insulin resistance, insulin insensitivity, and insulin unresponsiveness: A necessary distinction. Metabolism 27:18931902.

Kahn, S. E. 2003. The relative contributions of insulin resistance and beta-cell dysfunction to the pathophysiology of type 2 diabetes. Diabetologia 46:3-19.

Kerestes, M., V. Faigl, A. Kulcsar, O. Balogh, J. Foldi, H. Febel, Y. Chilliard, and G. Huszenicza. 2009. Periparturient insulin secretion and whole-body insulin responsiveness in dairy cows showing various forms of ketone pattern with or without puerperal metritis. Domest. Anim. Endocrinol. 37:250-261.

Mann, S., F. A. L. Yepes, M. Duplessis, J. J. Wakshlag, T. R. Overton, B. P. Cummings, and D. V. Nydam. 2016. Dry period plane of energy: Effects on glucose tolerance in transition dairy cows. J. Dairy Sci. 99:701-717.

Marett, L. C., M. J. Auldist, P. J. Moate, W. J. Wales, K. L. Macmillan, F. R. Dunshea, and B. J. Leury. 2015. Response of plasma glucose, insulin, and nonesterified fatty acids to intravenous glucose tolerance tests in dairy cows during a 670-day lactation. J. Dairy Sci. 98:179-189.

McCann, J. P., and T. J. Reimers. 1985. Glucose response to exogenous insulin and kinetics of insulin metabolism in obese and lean heifers. J. Anim. Sci. 61:612-618.

Muniyappa, R., S. Lee, H. Chen, and M. J. Quon. 2008. Current approaches for assessing insulin sensitivity and resistance in vivo: Advantages, limitations, and appropriate usage. Am. J. Physiol. Endocrinol. Metab. 294:E15-26.

NRC. 2001. Nutrient Requirements of Dairy Cattle. Vol. 1. 7th ed. Natl. Acad. Press, Washington, DC.

Oliveira, L. H., A. B. Nascimento, P. L. Monteiro Jr., M. M. Guardieiro, M. C. Wiltbank, and R. Sartori. 2016. Development of insulin resistance in dairy cows by 150 days of lactation does not alter oocyte quality in smaller follicles. J. Dairy Sci. 99:9174-9183.

Ospina, P. A., J. McArt, T. Overton, T. Stokol, and D. Nydam. 2013. Using nonesterified fatty acids and $\beta$-hydroxybutyrate concentrations during the transition period for herd-level monitoring of increased risk of disease and decreased reproductive and milking performance. Vet. Clin. North Am. Food Anim. Pract. 29:387-412.

Pacini, G., and R. N. Bergman. 1986. Minmod-A computer-program to calculate insulin sensitivity and pancreatic responsivity from the frequently sampled intravenous glucose-tolerance test. Comput. Methods Programs Biomed. 23:113-122.

Pires, J. A., A. H. Souza, and R. R. Grummer. 2007. Induction of hyperlipidemia by intravenous infusion of tallow emulsion causes insulin resistance in holstein cows. J. Dairy Sci. 90:2735-2744.

Regnault, T. R. H., H. V. Oddy, C. Nancarrow, N. Sriskandarajah, and R. J. Scaramuzzi. 2004. Glucose-stimulated insulin response in pregnant sheep following acute suppression of plasma non-esterified fatty acid concentrations. Reprod. Biol. Endocrinol. 2:64.

Rose, M. T., Y. Obara, F. Itoh, H. Hashimoto, and Y. Takahashi. 1997. Non-insulin- and insulin-mediated glucose uptake in dairy cows. J. Dairy Res. 64:341-353.

Schröder, U. J., and R. Staufenbiel. 2006. Invited review: Methods to determine body fat reserves in the dairy cow with special regard to ultrasonographic measurement of backfat thickness. J. Dairy Sci. 89:1-14.

Wallace, J. M., R. P. Aitken, and M. A. Cheyne. 1996. Nutrient partitioning and fetal growth in rapidly growing adolescent ewes. J. Reprod. Fertil. 107:183-190.

Wallace, J. M., P. Da Silva, R. P. Aitken, and M. A. Cruickshank. 1997. Maternal endocrine status in relation to pregnancy outcome in rapidly growing adolescent sheep. J. Endocrinol. 155:359-368.

Weber, C., C. T. Schaff, U. Kautzsch, S. Borner, S. Erdmann, S. Gors, M. Rontgen, H. Sauerwein, R. M. Bruckmaier, C. C. Metges, B. Kuhla, and H. M. Hammon. 2016. Insulin-dependent glucose metabolism in dairy cows with variable fat mobilization around calving. J. Dairy Sci. 99:6665-6679. 